PRACE GEOGRAFICZNE

zeszyt $154,2018,35-54$

doi: $10.4467 / 20833113$ PG.18.009.8965

Instytut Geografii i Gospodarki Przestrzennej UJ

Wydawnictwo Uniwersytetu Jagiellońskiego

\title{
KONCEPCJA GENTRYFIKACJI TURYSTYCZNEJ I JEJ WSPÓŁCZESNE ROZUMIENIE
}

\author{
Joanna Kowalczyk-Aniot
}

\section{The concept of tourism gentrification and its contemporary understanding}

\begin{abstract}
Contemporary cities are in a state of constant transformations, which in a great part of the world literature, including Polish, is considered in the context of the concept of gentrification (R. Glass). One of its newer developments is the concept of tourism gentrification proposed in 2005 by K.F. Gotham. This view well interprets today's cities where tourism has grown to the rank of an urban strategy of economic development. In recent years, the effects of urban tourism development have more and more often caused a widespread debate and tourist gentrification has been becoming a constitutive element in it. The insufficient presence of the tourism gentrification problem in Polish literature, especially in the field of urban tourism, was an inspiration to undertake the following research. The aim of the study is to present the concept of tourism gentrification of K.F. Gotham, its evolution and current understanding. The basic method is a review, mainly of English-language literature, and its critical analysis. The conclusions show that this concept is subject to expansion along with the transformation of tourism and cities. There are also differences in the recognition of the studied phenomenon from the perspective of urban studies and studies on tourism. Tourism gentrification becomes an important challenge for the 21st century city. It can be perceived as a simultaneous economic, physical, social and cultural influence exerted by the development of tourism and favourable revitalization processes (triggered by the market forces and actions of authorities), inseparably connected with the displacement of residents caused by tourism. Its effect is the transformation of the urban social space into the space of tourism and entertainment consumption. In extreme cases, tourism gentrification can take the total form - a collective displacement and replacement of residents with temporary users of urban space, unseen in the classical processes of gentrification.
\end{abstract}


Keywords: gentrification, tourism, city, tourism gentrification, urban tourism

Zarys treści: Współczesne miasta są w stanie ciągłych przeobrażeń, które znakomita część światowej, w tym polskiej literatury, rozpatruje w kontekście koncepcji gentryfikacji Glass. Jednym z jej nowszych rozwinięć jest koncepcja gentryfikacji turystycznej zaproponowana przez Gothama w 2005 r. Ujęcie to dobrze interpretuje dzisiejsze miasta, w których, jak zauważają Hoffman i in. (2003), turystyka urosła do rangi miejskiej strategii rozwoju gospodarczego. Obserwowane coraz częściej skutki rozwoju turystyki miejskiej wywołały w ostatnich latach szeroką debatę, w której gentryfikacja turystyczna staje się konstytutywnym elementem. Niewystarczająca obecność tematyki gentryfikacji turystycznej w polskim piśmiennictwie, zwłaszcza z zakresu turystyki miejskiej, była inspiracją do podjęcia badań w tym kierunku. Celem opracowania jest przedstawienie koncepcji gentryfikacji turystycznej Gothama (2005), jej ewolucji i aktualnego rozumienia. Zasadniczą metodą jest przegląd, głównie anglojęzycznej, literatury przedmiotu oraz krytyczna jej analiza. Wnioski pokazują, że koncepcja ta rozwija się wraz z przeobrażeniami turystyki i miast. Stopniowo rysują się też różnice w ujmowaniu zjawiska pomiędzy stanowiskami z perspektywy studiów miejskich i studiów nad turystyką. Gentryfikacja turystyczna staje się istotnym wyzwaniem dla XXI-wiecznego miasta. Należy ją postrzegać jako równoczesny ekonomiczny, fizyczny, społeczny i kulturowy wpływ wywierany przez rozwój turystyki i sprzyjających jej procesów rewitalizacji (uruchamianych przez siły rynku i działania władz), nierozłącznie związany z wyparciem mieszkańców powodowanym przez działalność turystyczną i aktywnością turystów. Jego skutkiem jest przekształcenie miejskiej przestrzeni społecznej w przestrzeń konsumpcji turystyczno-rozrywkowej. W skrajnych przypadkach gentryfikacja turystyczna może mieć formę totalną - zbiorowego wyparcia i zastąpienia mieszkańców czasowymi użytkownikami miejskiej przestrzeni, niespotykanego w klasycznych procesach gentryfikacji.

Stowa kluczowe: gentryfikacja, turystyka, miasto, gentryfikacja turystyczna, turystyka miejska

\section{Wprowadzenie}

Współczesne miasta są w stanie ciągłych przeobrażeń widocznych zwłaszcza w przestrzeni centralnej. Nowa forma i funkcjonowanie miast skłaniają zatem do poszukiwania różnych od tradycyjnych ujęć i koncepcji badawczych (Maik 2016). Jedną z nich jest koncepcja gentryfikacji Glass (1964), wyrosła ze społecznego nurtu studiów miejskich, która ma obecnie charakter interdyscyplinarny i uwzględnia różnorodność miejskiej rzeczywistości. Jak zauważa Maik (2016), badania nad gentryfikacją przyczyniają się do budowania wiedzy o postindustrialnym mieście podlegającym gruntownej restrukturyzacji, zwłaszcza do opisu mechanizmu zachodzących zmian. Koncepcja gentryfikacji podlega stałej dyskusji i ewolucji. Jednym z jej nowszych rozwinięć jest koncepcja gentryfikacji turystycznej zaproponowana przez Gothama w 2005 r. Ujęcie to dobrze interpretuje współczesne miasta, w których, jak zauważają Hoffman i in. (2003), turystyka urosła do rangi miejskiej strategii rozwoju gospodarczego. Obserwowane coraz częściej skutki rozwoju 
turystyki miejskiej wywołały w ostatnich latach szeroką debatę, w której gentryfikacja turystyczna staje się konstytutywnym elementem.

Pojęcie gentryfikacji turystycznej jest rzadko stosowane w polskim piśmiennictwie. Jako pierwszy przytoczył je, przywołując Gothama (2005), Grzeszczak (2010) w przeglądowej rozprawie na temat gentryfikacji. Stosunkowo najwięcej uwagi poświęciła mu dotychczas Kowalczyk-Anioł (2017), traktując jako proces współtworzący tzw. syndrom wenecki miast historycznych ${ }^{1}$. Jak zauważa Lew (2017), gentryfikacja jest bardzo często związana z planowaniem turystycznym, zwłaszcza z tzw. placemaking będącym w centrum uwagi współczesnego dyskursu o rozwoju miasta i turystyki. Niewystarczająca obecność tematyki gentryfikacji turystycznej w polskim piśmiennictwie, zwłaszcza z zakresu turystyki miejskiej, była inspiracją do podjęcia badań w tym kierunku².

Celem opracowania jest przedstawienie koncepcji gentryfikacji turystycznej Gothama (2005), jej ewolucji i aktualnego rozumienia. Zasadniczą metodą jest przegląd dostępnej, głównie anglojęzycznej, literatury przedmiotu oraz krytyczna jej analiza. Część z wykorzystanych prac, ze względu na ograniczony dostęp do ich wersji publikowanych, to referaty wygłoszone na międzynarodowych konferencjach udostępnione przez ich autorów. Praca składa się z pięciu części - wprowadzenia, ogólnego zarysu koncepcji gentryfikacji, szczegółowej prezentacji koncepcji Gothama (2005) oraz jej późniejszych ujęć, z eksponowaniem tych, które wydają się najbardziej poszerzać perspektywy badawcze. Całość zamyka podsumowanie oraz spis wykorzystanej literatury.

\section{Gentryfikacja - ogólne założenia koncepcji}

Znakomita część światowej, w tym polskiej literatury, dotycząca przemian zachodzących we współczesnych miastach rozpatruje je w kontekście koncepcji gentryfikacji. Jak zauważa Smith (2002), szczególny wzrost popularności tej koncepcji nastąpił od lat 90. XX w., jakkolwiek sama definicja gentryfikacji autorstwa brytyjskiej socjolog Glass (1964) pochodzi sprzed ponad pięćdziesięciu lat. W dużym uproszczeniu gentryfikację można przedstawić jako „proces transformacji osadnictwa, głównie wielkomiejskiego, polegający na wprowadzaniu się bogatszych ludzi do podupadłych dzielnic, ich odnawianiu i stopniowym wypieraniu dotychczasowych uboższych

\footnotetext{
${ }^{1} \mathrm{~W}$ pracy uwypuklono ponadto postsocjalistyczny kontekst tego zjawiska na Starym Mieście w Krakowie. Zobacz też: Kowalczyk-Anioł, Zmyślony (2017) - gentryfikacja turystyczna jako jedno ze źródeł współczesnych protestów miejskich oraz Kowalczyk-Anioł, Afshar (2018) - gentryfikacja turystyczna jako narzędzie rozwoju miasta (przykład Meszhed w Iranie).

${ }^{2}$ Autorka chce w tym miejscu podziękować Recenzentom za cenne merytoryczne uwagi i sugestie pomocne w nadaniu pracy finalnego jej kształtu.
} 
mieszkańców” (Grzeszczak 2010, s.10). Gentryfikacja może być inicjowana przez spontaniczne wolnorynkowe siły miejskiej odnowy, ale też przez działania władz lokalnych (m.in. Lisowski 1999; Węcławowicz 2007; Górczyńska 2015). Jadach-Sepioło (2009) podkreśla jej sprzężenie zwrotne z procesami rewitalizacji (por. też Parysek 2016), zaś Kaczmarek (1999) odróżnia od rewitalizacji przez ukierunkowanie na zmianę społeczną. Gentryfikacja jest ściśle związana z globalizacją - jest jej manifestacją i skutkiem (Sassen 1999). Smith (2002) zaznacza jej przestrzenną ekspansję oraz postrzega jako globalną miejską strategię przekształcania centrów miast (inner city), wręcz doskonałą ekspresję neoliberalnego urbanizmu (por. też Atkinson, Bridge red. (2005), natomiast Butler (2002) jako proces (prze)budowy klasowej (re)formation).

Gentryfikacja jest procesem uzależnionym od kontekstu i lokalnych uwarunkowań, stąd adaptacja tej koncepcji wymaga głębszej refleksji i ostrożności. Do tradycyjnych cech zjawiska gentryfikacji należą: fizyczna odnowa zasobów mieszkaniowych na gentryfikowanym terenie, zmiana stosunków własności, wzrost cen gruntów i budynków oraz zmiana składu społecznego (wymiana klasowa) - napływ ludności o wyższym statusie społeczno-ekonomicznym i stopniowy odpływ dotychczasowych mieszkańców (ludności uboższej) - zob. Szafrańska (2012), Górczyńska (2015). Współcześnie powszechnie przyjmuje się, iż gentryfikacja jest czymś więcej niż „uszlachetnianiem” zasobów mieszkaniowych. Jest istotnym czynnikiem transformacji miasta, przestrzennym elementem jego przekształceń społecznych związanych z globalizacją i zmianą bazy ekonomicznej miasta (Maik 2013). Za głównych aktorów miejskiej gentryfikacji (tzw. gentryfierów) przyjęto traktować szeroko rozumianą tzw. nową klasę średnią (miejscy profesjonaliści), nową klasę kulturalną (wykonującą zawody związane z kulturą, nauką i sztuką) oraz klasę kreatywną w rozumieniu Floridy (Górczyńska 2015). Badania gentryfikacji w ujęciu popytowym odnoszą się zwykle do stylu życia i konsumpcji oraz cech społeczno-demograficznych gentryfierów (np. Zukin 1989; Ley 2003; Murzyn-Kupisz, Szmytkowska 2015; Murzyn-Kupisz, Działek 2017). W drugim - podażowym - podejściu przedmiotem uwagi jest wyjaśnianie uwarunkowań i czynników ekonomicznych gentryfikacji. Postrzegając gentryfikację jako rezultat luki renty gruntowej (Smith 1979; Sagan 2017), wskazuje się, że pojawia się ona najszybciej na obszarach, w których różnice między istniejącą a potencjalną rentą gruntową (możliwą do osiągnięcia w efekcie odnowy, przebudowy lub zmiany sposobu użytkowania istniejących struktur) są największe. Karwińska (2008), na podstawie zmian w gentryfikowanych dzielnicach, wyróżnia gentryfikację społeczną, ekonomiczną i symboliczną (kulturową), którą wiąże ze wzrostem prestiżu danego miejsca.

Jak zauważa Grzeszczak (2010) w przeglądowej pracy poświęconej gentryfikacji, jej definicja podlega ciągłej dyskusji. Część badaczy opowiada się za podejściem klasycznym i restrykcyjnym rozumieniem zjawiska, w którym elementem 
konstytutywnym jest proces wypierania. Inni proponują ujęcie inkluzywne - modyfikując i rozszerzając definicję Glass, dopuszczając pominięcie wymiany klasowej (por. Jakóbczyk-Gryszkiewicz red. 2012). Ewolucję zakresu pojęciowego pośrednio ilustruje falowy model procesu gentryfikacji, wypracowany przez Hackworth i Smith (2001), który Lees i in. (2008) rozszerzają o najnowszy etap, tzw. gentryfikację czwartej fali. Jego główną cechą jest rozwój gentryfikacji w oparciu o działania władz państwowych i politykę publiczną miast (por. m.in. Lees, Ley 2008; Jakóbczyk-Gryszkiewicz i in. 2014; Parysek 2016; Główczyński 2017; Sagan 2017). Aktualne prace dotyczące gentryfikacji (m.in. Gaffney (2015) coraz częściej pokazują relokacje wielotysięcznych społeczności związane z realizacjami megaprojektów miejskich, zwłaszcza w miastach globalnego Południa, a zarazem akcentują w toczącej się debacie akademickiej opór, mobilizację i aktywizm społeczny towarzyszący gentryfikacji (por. praktyki przeciwdziałające gentryfikacji - Lees i in. 2018).

Wieloaspektowy charakter procesu skutkuje wyróżnianiem różnych form gentryfikacji miejskiej (Lees, Philips red. 2018). Należą do nich np.: studentyfikacja (m.in. Gaczek i in. 2006; Smith 2008; Murzyn-Kupisz, Szmytkowska 2015; Rewers 2015, por. też „beanizacja” - Zborowski 2005), super-gentryfikacja (Lees 2003), zielona gentryfikacja (m.in. Gould, Lewis 2012; Łaszkiewicz i in. 2018; Anguelovski i in. 2018) czy gentryfikacja turystyczna, której poświęcono dalszą część opracowania.

\section{Gentryfikacja turystyczna - założenia koncepcji K. F. Gothama}

Jedną z form gentryfikacji jest gentryfikacja turystycæna zdefiniowana przez amerykańskiego socjologa Gothama (2005) i opisana w artykule pt. Tourism gentrification: The case of New Orleans' Vieux Carre (French Quarter) na łamach czasopisma Urban Studies na przykładzie Dzielnicy Francuskiej w Nowym Orleanie. Według autora koncepcja ta wyjaśnia przemianę przestrzeni społecznej średniej klasy w ekskluzywną enklawę charakteryzującą się szybkim wzrostem miejsc rozrywki (zwłaszcza korporacyjnej, zbiorowej) i turystyki. Jak podkreśla Gotham, gentryfikację turystyczną wyróżniają nie intensywność czy wielkość, lecz wzorce wpisane w jej proces. Twierdzi, że gentryfikacja turystyczna jest bardziej złożona niż klasyczna jej forma - ma charakter handlowy (komercyjny) i mieszkaniowy, a zarazem pokazuje nowe powiązania między instytucjami lokalnymi, rynkiem nieruchomości i globalną gospodarką. Gotham podkreśla, że gentryfikacja turystyczna stanowi wyzwanie dla tradycyjnych badań procesów gentryfikacji, które zakładały podażowe lub popytowe jej czynniki. Dowodzi, że proces ten nie jest wynikiem preferencji grupowych ani też nie odzwierciedla rynkowych praw podaży i popytu. Rozpatrywany przez niego przykład Dzielnicy Francuskiej pokazał, że transformacja w przestrzeń rozrywki 
(entertainment destination) zwiększa znaczenie działań zorientowanych na konsumpcję i sprzyja gentryfikacji. Z jednej strony rozrywka i turystyka przyciągnęły do dzielnicy bardziej elitarną i zamożną grupę oraz krajowe sieci handlowe i zwiększyły wartość nieruchomości, z drugiej zaś rozrywka i turystyka wypchnęły klasę robotniczą i erodowały artystyczny charakter Vieux Carre. Finalnie jednak wzrost tzw. turystyki korporacyjnej i rosnąca penetracja globalnych firm z sektora rozrywki spowodowała przeniesienie praw własności z małych grup i osób na międzynarodowych turystycznych inwestorów wpływających na funkcjonowanie tej dzielnicy. Gotham zauważa, że szeroko propagowane twierdzenie, iż klasa kreatywna i „pośrednicy kultury” (nowa klasa kulturalna) prowadzą do gentryfikacji, pomija złożone i wielowymiarowe efekty globalnych przemian społeczno-ekonomicznych i silną rolę kapitału korporacyjnego w organizacji oraz rozwoju gentryfikowanych przestrzeni.

Warto w tym miejscu podkreślić amerykańskie tło budowania Gothamowej koncepcji. W przemianach społeczno-ekonomicznych miast amerykańskich ostatnich dekad XX w. istotne było tworzenie nowego konkurencyjnego środowiska (dającego możliwości rozwoju nowych narzędzi i subwencji), by przyciągnąć inwestycje i wykreować się jako ośrodki turystyczne (tourist destination). W tym nowym kontekście wiele dotychczas typowo mieszkalnych i handlowych przestrzeni stało się centrami spektaklu i konsumpcji turystycznej, a wizję tego rozwoju można określić, nawiązując do dyskusji Lloyd i Clark (2002), koncepcją „miasta jako maszyny rozrywki” (,city as an entertainment machine”) (Gotham 2005). W efekcie, jak zauważa Gotham, w wielu miejskich dzielnicach postępuje rozpowszechnianie różnych, ale tematycznie podobnych, turystycznych enklaw obejmujących dzielnice historyczne, przestrzenie kultury, obszary miejskiej rekreacji i rozrywki. Podkreśla, że lokalny, a nawet krajowy rynek nieruchomości często nie jest w stanie sprostać finansowaniu projektów rewitalizacji i rozwoju zagospodarowania turystycznego. Wzrost sekurytyzacji w latach 80 . i 90. XX w. i rozwój nowych źródeł finansowania amerykańskiej gospodarki sprawił, że inwestorzy instytucjonalni zaczęli chętnie finansować miejskie projekty rozrywkowo-turystyczne. To skłoniło Gothama do wyciągnięcia wniosku, iż gentryfikacja i turystyka są napędzane w dużym stopniu przez wielkie firmy finansowe i korporacje rozrywkowe, które zbudowały sieć powiązań instytucjonalnych z tradycyjnymi miejskimi partnerami wspierającymi (city boosters) komercjalizację miast i ich przestrzeni społecznych (dzielnic).

Ze względu na wykorzystywanie turystyki jako strategii rewitalizacji gospodarczej usługi i obiekty turystyczne są włączane do przebudowywanych i gentryfikowanych

\footnotetext{
${ }^{3}$ Szerzej na temat tej koncepcji w polskim piśmiennictwie pisali: Derek (2011), Kowalczyk, Derek (2015) i Bartkowski (2016).
} 
stref. W tym nowym miejskim krajobrazie gentryfikację i turystykę zespolono z innymi przestrzeniami i formami konsumpcji (handlem, gastronomią, obiektami kultury i rozrywki). To wymieszanie rozrywki, działalności handlowej i przestrzeni mieszkalnej prowadzi do zmiany relacji między kulturą a gospodarką w wytwarzaniu i konsumpcji przestrzeni miejskiej.

Ambicją Gothama było rozszerzenie spektrum analizy gentryfikacji i przeniesienie rozważań nad zjawiskiem turystyki poza wąskie ujęcie przepływu, wpływu i form. Zamierzał wyjaśnić większe siły społeczne, które oddziałują na gentryfikację i uwydatniają newralgiczne kwestie miejskie - restrukturyzację i przemiany społeczno-kulturowe. Przywołując Smitha i DeFilipps (1999), ściśle wiązał gentryfikację z globalnymi inwestycjami kapitałowymi. Podążając za tą myślą, konkludował, że analiza turystyki może wyjaśniać przyczyny i skutki gentryfikacji lepiej niż dotychczasowe poszukiwania badawcze. Turystyka, jak argumentował, jest częścią wzrostu konsumpcji i rosnącego znaczenia wytwarzania dóbr kultury, obrazów dziedzictwa kulturowego oraz innych symulakrów ${ }^{4}$. Jest zarazem dynamicznym procesem obejmującym społeczne interakcje, związki i konflikty, które mają globalny i złożony charakter. Postulował, że ze względu na obserwowane w wielu miastach zwracanie się do turystyki jako środka rozwoju gospodarczego, a zarazem ekspansję gentryfikacji, potrzebne są wnikliwe badania powiązań obu tych zjawisk.

Według danych z wyszukiwarki google.scholar artykuł Gothama (2005) jest najczęściej cytowaną pracą naukową, w której pojawia się określenie tourism gentrification. Przywoływana coraz częściej w ostatnich pięciu latach omówiona koncepcja (w tym przez nielicznych polskich autorów - Grzeszczak 2010, Kowalczyk-Anioł 2017), podejmowana m.in. przez socjologów, geografów, architektów, planistów podlega licznym modyfikacjom. Jednocześnie, co należy zaznaczyć, powstają prace (np. Bardzińska-Bonenberg 2012; Murzyn-Kupisz 2012), które z perspektywy makro opisują turystykę i gentryfikację.

\section{Współczesne rozumienie zjawiska gentryfikacji turystycznej}

Dynamiczny rozwój turystyki miejskiej, jej nieustanne przeobrażenia oraz rozpowszechnianie się zjawiska gentryfikacji w przestrzeni geograficznej, a także stale zmieniające się miasta, stawiają nowe wyzwania w badaniach nad gentryfikacją

\footnotetext{
${ }^{4}$ Symulakr, symulakrum - „kopia bez oryginału, znak bez odniesienia ... Udaje on tylko, że coś z niego znaczy, symuluje znaczenie" (Szahaj 2004, s. 81). Termin upowszechniony przez francuskiego filozofa Baudrillarda (2005) wraz z koncepcją ewolucji znaków (teoria symulacji). O turystyce, przemianach przestrzeni i symulakrach pisali m.in. Minca (2000) oraz Lniany (2015).
} 
turystyczną. Powstające opracowania stanowią zwykle rozwinięcia ujęcia Gothama (m.in. Herrera i in. 2007; Bures, Cain, 2008; Hiernaux, González 2014a; Cócola-Gant 2015; Liang, Bao 2015; Gravari-Barbas, Guinand 2017; Opillard 2017), choć zdarzają się prace nawiązujące do zjawiska gentryfikacji turystycznej ujmujące je w pojęciach turystyfikacji i gentryfikacji (np. Nofre i in. 2017; Novy 2017)5. Część modyfikacji koncepcji Gothama wynika z rozszerzania zakresu przedmiotowego zjawiska, większość z odmienności kontekstu terytorialnego. Wydaje się zatem bardziej zasadne mówić nie o procesie, lecz o procesach gentryfikacji turystycznej, które rozprzestrzeniły się od miast amerykańskich (m.in. Bures, Cain 2008; Opillard 2017) i europejskich (np. Herrera i in. 2007; Janoschka i in. 2014; Cócola-Gant 2016; Minoia 2017; Pinkster, Boterman 2017; Mermet 2017) po miasta krajów rozwijających się, m.in. Chiny (Shin 2010; Liang, Bao 2015), Meksyk (Hiernaux, González 2014b), Argentyna (Skoll, Korstanje 2014; Sequera, Rodríguez, 2017), czy szerzej Amerykę Łacińską (Janoschka i in. 2014).

Gentryfikacja turystyczna, jakkolwiek trudna do wychwycenia i zrozumienia, jest istotną siłą przekształcającą krajobrazy i oblicza społeczno-ekonomiczne dzisiejszych miast (Gravari-Barbas, Guinand 2017). Od kiedy jednak rozwój turystyki zaczyna być procesem gentryfikacji? Jak zauważyły wspomniane autorki, trudno jednoznacznie odpowiedzieć na to pytanie - ponieważ turystyka w swojej naturze już we wczesnym stadium wywierała wpływ na odwiedzane miejsca m.in. przez wprowadzanie nowej infrastruktury i usług, z czasem przybrała też formę i perspektywę „turystycznego klosza” (Judd 1999; Urry 2007) wnoszonego w miejsca i krajobrazy.

Bez wątpienia odnowa miasta (rewitalizacja jego fragmentów), rozwój turystyki i gentryfikacja wzajemnie na siebie oddziałują (ryc. 1). Gravari-Barbas i Guinand (2017) widzą najczęstszą relację tego związku w czasie jako początkowo stabilną:

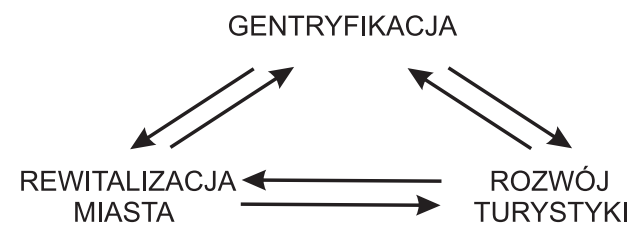

Ryc. 1. Relacje między rewitalizacją miasta, gentryfikacją i rozwojem turystyki

Figure 1. Relationships between urban regeneration, gentrification and tourism development

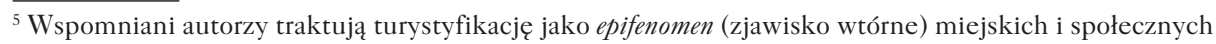
procesów: tzw. zwrotu rekreacyjnego i gentryfikacji postindustrialnego miasta.
} 
wczesna gentryfikacja może ,zachęcać” turystykę i pobudzać jej rozwój, a w następnym etapie może ją zaciekle zwalczać. Turystyka, zazwyczaj traktowana jako skutek gentryfikacji, może również ją poprzedzać. Większość autorów podobnie jak Gotham (2005) eksponuje nieliniowy, złożony charakter tych relacji. Rozmaite powiązania, zwłaszcza między turystyką a gentryfikacją, powodują, że gentryfikacja turystyczna jest współcześnie wieloznacznym terminem i może się odnosić do:

a) rozwoju turystyki jako katalizatora gentryfikacji,

b) turystów, którzy stają się aktorami gentryfikacji,

c) ewolucji struktury społecznej ruchu turystycznego w obszarze recepcji (Chapuis i in. 2015).

Gentryfikacja turystyczna może zatem mieć różne formy:

- nowo wybudowanej gentryfikacji (new-build gentrification), która z czasem stymuluje gentryfikację mieszkaniową, np. Baltimore's Inner Harbor (Gotham 2005), Shenzhen Overseas Chinese Town w chińskim Shenzhen (Liang, Bao 2015); - pionierskiej gentryfikacji turystycznej (początki turystyki off the beaten track);

- „zasadniczej” gentryfikacji turystycznej (która bezpośrednio i/lub pośrednio wypiera tradycyjnych mieszkańców i pionierów gentryfikacji, zastępując stałych użytkowników tej przestrzeni użytkownikami czasowymi - turystami, odwiedzającymi, studentami i innymi konsumentami oferty rozrywkowo-kulturalnej wykreowanej w tej przestrzeni), np. SoHo w latach 90. XX w. (Zukin 2008), współcześnie Berlin-Kreuzberg (Füller, Michel 2014), czeska Praga (Dumbrovská 2017), irański Meszhed (Kowalczyk-Anioł, Afshar 2018), Kazimierz w Krakowie (Murzyn-Kupisz 2012);

- super-gentryfikacji turystycznej (analogicznie do super-gentryfikacji Lees (2003), czyli kolejnej fali gentryfikacji, która wypiera wcześniejszych gentryfierów), np. opisana przez Gothama Dzielnica Francuska; Santa Cruz de Tenerifa (Herrera i in. 2007); współcześnie Canal District w Amsterdamie (Pinkster, Boterman 2017) i La Marais w Paryżu (Gravari-Barbas 2017).

W klasycznym definiowaniu gentryfikacji szczególnie istotna jest analiza procesu wypierania (displacement). Koncept Gothama już w 2007 r. zastosował Smith (amerykański twórca strukturalistycznego ujęcia gentryfikacji) wraz z kolegami z La Laguna na Teneryfie do analizy przypadku Santa Cruz (Herrera i in. 2007). W tej jednej z pierwszych prac poświęconych gentryfikacji turystycznej w kontekście europejskim autorzy wykazali związki między kolejną falą gentryfikacji a publicznymi strategiami rozwoju turystyki (state-led tourism gentrification) oraz ściśle związanym z nimi wyparciem lokalnej społeczności. Inwestycje realizowane w ramach programów i środków Unii Europejskiej jako istotny czynnik gentryfikacji wskazał również Morell (2009) na przykładzie Palma de Mallorca (zob. też Janoschka i in. 2014). Displacement, który należy traktować jako konstytutywną, a zarazem budzącą najwięcej emocji i protestu społecznego składową współczesnej gentryfikacji turystycznej (Kowalczyk-Anioł, 
Zmyślony 2017; Mermet 2017), może mieć wiele wymiarów. Cócola-Gant (2016) podkreśla, że napędzane turystyką procesy wypierania (tourism-driven displacement) są współcześnie zasadniczym obliczem gentryfikacji (the new gentrification battlefront) w wielu miastach świata. Ich signum tempori w drugiej dekadzie XXI w. stanowi rugowanie mieszkańców powodowane przez rozpowszechniane za pomocą globalnych portali internetowych (np. Airbnb, tzw. gospodarki współdzielenia (sharing economy) - zob. Pawlusiński 2017) form bezpośredniego krótkoterminowego wynajmu turystycznego (Airbnb-led tourism gentrification - Yrigoy (2016) ${ }^{6}$. Analizując sytuację w Barcelonie, Cócola-Gant (2016) wskazuje na wspólne występowanie mechanizmów typowych dla gentryfikacji turystycznej - bezpośredniego (direct displacement) oraz związanego z „presją wypierania” (displacement pressure - Marcuse 1985) pośredniego wyparcia (indirect displacement). Zmianę społeczną, która jest konsekwencją nakładania się obu form wyparcia i działania na zasadzie „śnieżnej kuli”, określa jako collective displacement (Cócola-Gant 2016). W podobnym kontekście Gravari-Barbas i Guinand (2017) wskazują na Airbnb jako „maszynę gentryfikacji” w głównych ośrodkach turystycznych i metropoliach. Mermet (2017) pisze o „syndromie Airbnb” w Reykjaviku, zaś Opillard (2017), odnosząc się do idei sharing economy i Airbnb oraz obserwowanych skutków społecznych, używa wręcz określenia „lukrowanie”, podkreślając rozdźwięk między ideą współdzielenia a faktycznymi jej przesłankami i konsekwencjami. Zamiana zasobów mieszkalnych w zakwaterowanie dla odwiedzających (m.in. jako rezultat luki renty gruntowej - Smith 1979) skutkuje zmianami w miejskich sąsiedztwach. Wiąże się m.in. z zanikiem więzi społecznych i utratą tożsamości, ale też sprzeciwem i oporem społecznym (Novy 2017). Odmienne spojrzenie demonstrują Stors i Kagermeier (2016). Twierdzą oni, że pełne zrozumienie i uchwycenie zjawiska jest niezwykle trudne, a wpływ internetowych platform peer to peer na rynek nieruchomości jest przeszacowany. Bezsprzeczne jest jednak, że pomimo deklarowanego nowego modelu rozwoju, który ma przyczynić się do deglomeracji i zmniejszania presji turystycznej, fenomen Airbnb pokazuje te same przestrzenne wzorce co tradycyjny sektor gościnności (hotele, gastronomia) koncentrując się wokół największych atrakcji turystycznych miasta i przyspieszając gentryfikację obszarów centralnych, zwykle cennych historycznie (Quaglieri, Scarnato 2017; Kowalczyk-Anioł 2017). W wielu miastach (m.in. Barcelonie, Rzymie, Krakowie) eksplozję turystycznej gospodarki współdzielenia poprzedził w końcu

\footnotetext{
${ }^{6}$ Rozwój nowoczesnych technologii zmienia współczesną turystykę i wywiera rosnący wpływ na miasto. Obok opisanych szerzej w artykule związków gospodarki współdzielenia i platform peer to peer z gentryfikacją turystyczną można zauważyć coraz większą siłę przetargową informatycznych korporacji transnarodowych (np. Google), które poprzez big data redefiniują dostępność przestrzeni miejskiej, sposób jej użytkowania i gospodarowania, tworząc w konsekwencji kolejne wymiary wykluczenia społecznego mieszkańców. Shaw i Graham (2017) sugerują wręcz w odwołaniu do Lefebvre'a refleksję nad ,informatycznym prawem do miasta”.
} 
XX w. rozwój taniej bazy noclegowej - głównie hosteli i obiektów typu bed \& breakfast, zlokalizowanych często w historycznej tkance mieszkaniowej i bezpośrednim sąsiedztwie stałych mieszkańców. Ich presja została zintensyfikowana przez wzrastającą dostępność czasową i komunikacyjną (rozwój niskobudżetowych połączeń lotniczych) oraz powszechną dostępność internetowych systemów rezerwacyjnych i wspomnianych platform peer to peer (m.in. Gutiérrez i in. 2017; Guttentag 2015). Internet, szczególnie technologia Web 2.0, przyczynił się zwłaszcza do gwałtownego rozwoju nieformalnego, indywidualnego zakwaterowania turystycznego, nadając mu zarazem nowe cechy (Russo, Quaglieri 2014), w tym dużą rolę czynnika gentryfikacji mieszkaniowej. Gentryfikacja turystyczna obejmuje bowiem zarówno gentryfikację mieszkaniową (najczęściej eksponowaną przez procesy wypierania), jak i usługową (handlową - Grzeszczak 2010; commercial - Gotham 2005). Pierwsza podnosi wartość nieruchomości i wynajmu lokali mieszkalnych, ale też powoduje wzrost i przestrzenną ekspansję zakwaterowania turystycznego (hoteli, hosteli, obiektów $b \& b$ ), drugich domów i ofert gospodarki współdzielenia. Gentryfikacja usługowa przekształca lokalny rynek dla potrzeb gospodarki gościnności (visitors economy) - zastępuje lokalne niezależne sklepy i usługi podstawowe franczyzowymi, sieciowymi punktami (bary, fast food, kawiarnie, sklepy z pamiątkami), obiektami luksusowej konsumpcji globalnych marek (np. modowych), podnosi ceny wynajmu lokali użytkowych i konsumpcji (Novy, Colomb 2016). Oba omówione procesy są mocno zaakcentowane w definicji gentryfikacji turystycznej zaproponowanej przez Cócola-Gant (2015). Autor ten widzi w niej proces społeczno-przestrzennej zmiany, w której lokalne sąsiedztwa podlegają przeobrażeniom w celu zaspokojenia potrzeb zamożnych konsumentów - zarówno mieszkańców, jak i odwiedzających.

Opillard (2017), wychodząc od definicji Gothama, rozszerza zakres znaczeniowy gentryfikacji turystycznej o konsekwencje jej zmian oraz podkreśla procesy przyśpieszające i przeciwdziałające przeobrażeniom gentryfikowanych przestrzeni. Stała batalia przeciw wymazywaniu zbiorowej pamięci leży jego zdaniem w sercu procesów gentryfikacji, jako że zarówno komodyfikacja zbiorowej pamięci i zapominanie tego, co było, zanim powstały nowe obiekty turystyczno-rozrywkowe, są newralgiczne dla kreowania miejsc zgentryfikowanej konsumpcji. Uczony analizował gentryfikację turystyczną w dwóch odmiennych kontekstach - polityki miejskiej dającej priorytet ochronie dziedzictwa (we wpisanym na Listę Światowego Dziedzictwa UNESCO chilijskim Valparaiso) oraz w obliczu problemów związanych z rozwojem sharing economy (w amerykańskim San Francisco). W obu przypadkach punkt ciężkości związany był z procesami wysiedlania mieszkańców (dispossession), powodowanymi napływem kapitału turystycznego oraz społeczną odpowiedzią na nie poprzez protesty społeczne. Koncepcja gentryfikacji turystycznej daje zdaniem Opillarda możliwość identyfikacji sposobów, w jakich zmieniały się „krajobrazy władzy”. Obok podkreślanej w nawiązaniu do Gothama wzajemnej zależności między globalnymi 
i lokalnymi siłami autor zwrócił uwagę na nowe instytucjonalne powiązania między aktorami publicznymi i prywatnymi.

Gotham (2005) argumentował, że koncepcja gentryfikacji turystycznej uwydatnia globalne i lokalne procesy nakładające się w miejskiej odnowie, podkreślał zasadnicze znaczenie korporacyjnego przemysłu turystycznego (łańcuchy i sieci hotelowe, wypożyczalnie samochodów, touroperatorzy). Gravari-Barbas i Guinand (2017), obserwując współczesny rozwój gentryfikacji turystycznej, twierdzą, że lokalni aktorzy, mieszkańcy, jak i turyści także mają swój niemały udział w tym zjawisku. Ponadto, odnosząc się do założenia gentryfikacji turystycznej jako dostarczającej koncepcyjnego związku między stroną produkcyjną a stroną popytu, wskazują, że aktorzy ,przeplatają się" wzajemnie w tym procesie (zob. też Hiernaux, González 2014). Turystyka często podąża za aktorami gentryfikacji, np. artystami - będącymi często inicjatorami, pionierami gentryfikacji (Działek, Murzyn-Kupisz 2015) i inwestuje w „ponownie odkryte” obszary miejskie (np. nowojorskie SoHo - Zukin 2008). Richards (2014) podkreśla, że wiele modnych miejskich obszarów przechodzi intensywną gentryfikację nierzadko wspieraną przez strategie rozwoju kreatywności. Wskazuje też, iż wobec obserwowanych zmian centrum „kreatywne aktywności” przesuwa się w kierunku „kreatywnych przedmieść”, co zdaniem Działka i Murzyn-Kupisz (2015) coraz częściej bywa stymulowane przez miejskie programy rewitalizacji kolejnych obszarów problemowych (por. strategia alternatywnej turystyfikacji - Baudry (2017); artification - Gravari-Barbas, Guinand 2017). Jednocześnie częstym czynnikiem gentryfikacji turystycznej jest odnowa historycznej tkanki miejskiej (nierzadko skutkująca komodyfikacją, ale też estetyzacją przestrzeni), jak i prowadzona przez miasto restrykcyjna polityka ochrony dziedzictwa (zwłaszcza miejsc z listy UNESCO), pośrednio sprzyjające wypieraniu mieszkańców (m.in. Bures i Cain 2008; Janoschka i in. 2014; Opillard 2017). Gravari-Barbas i Guinand (2017) określają te mechanizmy jako syndromy muzeifikacji i heritagizacji. Jak podkreśla Jansen-Verbeke (2011) „tworzenie miejskich krajobrazów turystycznych”, głęboko zakorzenione we współczesnych trendach społecznych i kulturowych, jest napędzane przez gospodarkę kulturową (cultural economy) zamieniającą dobro kultury w dobro rynkowe.

\section{Turyści jako aktorzy gentryfikacji}

Turystów przyciąga tętniące życiem i różnorodnością miasto, zwłaszcza nasycona funkcjami kulturalno-rozrywkowymi zrewitalizowana przestrzeń miejska, którą zarazem sami gentryfikują. Zauważalnie wzrasta ich znaczenie wśród użytkowników miejskiej przestrzeni (city users - Martinotti 1996; Kotus i in. 2015; por. też city visitors - Judd 2003). Uwzględniając kryterium aktorów gentryfikacji, turyści mogą być pionierami gentryfikacji, jak i właściwymi gentryfierami. 
Analizując wpływ turystyki off the beaten path na społeczność Harlemu, Hunning i Novy (2006) pokazali, że sprzyja ona gentryfikacji. W niecałą dekadę później m.in. Hiernaux i González (2014a), Gravari-Barbas i Guinand (2017), nawiązując do coraz bardziej popularnej formy turystyki off the beaten track (Maitland, Newman 2009), wskazują na uczestniczących w niej turystów eksploratorów, jak i globalnych turystów związanych z typem turystyki live like a local, as if residents jako międzynarodowych nowych gentryfierów. Jak twierdzi Bock (2015), szukają oni zwyczajnych, ale pełnych życia i różnorodnych dzielnic oraz kawiarni, barów i lokalnych targów, które były wcześniej prawie wyłącznie odwiedzane przez lokalną społeczność. Poszukiwanie autentyczności lokalnego życia wiąże się także z możliwościami (technologicznymi, społecznymi i ekonomicznymi) życia międzynarodowych elit w wybranych miejscach świata (Chapuis i in. 2015). Dla tych kosmopolitycznych aktorów gentryfikacji turystyka jest jednym z elementów stylu życia i tożsamości, związanej nierozerwalnie z przestrzenią konsumpcji (Minoia 2017). Istotne zmiany w zachowaniach turystycznych (Bock 2015), jak i opisanych wcześniej preferencjach, zaprowadziły turystykę w ostatnich latach do dawnych robotniczych i odległych dzielnic, które stały się atrakcyjne i turystycznie oznaczone (Gravari-Barbas, Guinand 2017). Zjawiska te zmieniają obraz i strukturę społeczną kolejnych części metropolii. Tworzą nowe, inne drogi gentryfikacji.

Wraz z upowszechnianiem gospodarki współdzielenia i platform sharingowych turystyka i turyści stają się dziś dodatkowym wyzwaniem dla gospodarki mieszkaniowej w miastach. W kolejnych gentryfikowanych turystycznie dzielnicach mieszkania i apartamenty są proponowane nie tylko lokalnej i krajowej klasie wyższej czy międzynarodowej elicie posiadaczy drugich domów, ale też masowym turystom. W tym tkwi zasadnicza zmiana - gentryfikacja turystyczna włącza nie tylko grupy z wyższego segmentu stratyfikacji społeczno-ekonomicznej, lecz także mniej zamożnych turystów masowych, którzy partycypując w gospodarce współdzielenia, stają się głównymi aktorami gentryfikacji historycznych centrów miast i innych miejskich obszarów (Hiernaux i González 2014a; Cócola-Gant 2015; Gravari-Barbas, Guinand 2017).

Warto w tym miejscu pokreślić postsocjalistyczną perspektywę turystyki i turysty masowego jako aktorów gentryfikacji. W atrakcyjnych turystycznie byłych socjalistycznych metropoliach (np. Praga, Budapeszt, Kraków), obok wymienionych wcześniej czynników, duża atrakcyjność ekonomiczna (cenowa) przyciąga turystów niskobudżetowych szukających taniej rozrywki, którzy m.in. jako aktorzy stag and hen tourism czy pub-crawls (Dumbrovská, Fialová 2014; Iwanicki i in. 2016) są źródłem bezpośredniego i pośredniego wypierania mieszkańców (Dumbrovská 2017; Kowalczyk-Anioł 2017). Gentryfikacja turystyczna z udziałem masowej i bardzo zdemokratyzowanej turystyki widoczna jest tu nie tylko w wymiarze społecznym i ekonomicznym, lecz także symbolicznym - jednak nie w charakterze prestiżowym, jak wskazywała Karwińska (2008), lecz rosnących kontrowersji. 


\section{Podsumowanie}

Wprowadzony przez Gothama do szeroko dyskutowanej koncepcji gentryfikacji czynnik turystyki - pozornie błahy z perspektywy miasta jako struktury długiego trwania - urósł dziś do rangi istotnej kwestii miejskiej. Przedstawiona w artykule koncepcja gentryfikacji turystycznej wydaje się być dobrą ramą koncepcyjną dla wyjaśniania globalnych i lokalnych procesów i sił przeobrażających współczesne miasta. Koncepcja ta, wprawdzie względnie młoda, podlega ewolucji i rozbudowie wraz z przeobrażeniami turystyki i miast, których dotyczy, oraz wyzwań im towarzyszących. Jak zauważa Opillard (2017), koncepcja gentryfikacji turystycznej jest efektywna i przydatna także do analizy lokalnych skutków transformacji i interwencji nowych aktorów w miastach, które doświadczają współcześnie konsekwencji (coraz częściej negatywnych) napływu kapitału i ruchu turystycznego. W określaniu zawiłych relacji między turystyką a gentryfikacją największym wyzwaniem wydaje się odróżnienie czynników „turystycznych” od innych determinant prowadzących do przemian miejskich przestrzeni społecznych oraz dychotomiczne ujęcie popytu i podaży.

Dokonana analiza pokazuje, iż zarysowały się dwie perspektywy: autorzy traktujący o gentryfikacji turystycznej z perspektywy studiów miejskich odnoszą się do niej jako do procesu przemian związanych z rozwojem turystyki (i rozrywki) w mieście, którego cechą konstytutywną jest wypieranie mieszkańców. Natomiast autorzy traktujący zjawisko ze stanowiska szeroko rozumianych nauk o turystyce raczej ujmują gentryfikację turystyczną jako skrajny, oceniany jednoznacznie negatywnie, etap i/lub efekt turystyfikacji miasta.

Gentryfikacja turystyczna, wpisując się w neoliberalne koncepcje rozwoju miast promowane od końca lat 80 . ubiegłego wieku, staje się istotnym wyzwaniem dla XXI- wiecznego miasta. Zdaniem autorki należy ją postrzegać jako równoczesny ekonomiczny, fizyczny, społeczny i kulturowy wpływ wywierany przez rozwój turystyki i sprzyjających jej procesów rewitalizacji (uruchamianych przez siły rynku i działania władz), nierozłącznie związany z wyparciem mieszkańców powodowanym przez działalność turystyczną, i aktywnością turystów. Jego skutkiem jest przekształcenie miejskiej przestrzeni społecznej w przestrzeń konsumpcji turystyczno-rozrywkowej. W skrajnych przypadkach gentryfikacja turystyczna może mieć formę totalną - zbiorowego wyparcia mieszkańców i zastąpienia ich czasowymi użytkownikami miejskiej przestrzeni, niespotykanego w klasycznych procesach gentryfikacji.

Parafrazując słowa Groyeckiej (2014), można stwierdzić, że gentryfikacja turystyczna to słowo-klucz, niezbędne, aby zrozumieć dynamikę zmian w dzisiejszej miejskiej przestrzeni społecznej, jak i turystyce miejskiej. Rodzą się pytania: w jakim stopniu i w jakich wymiarach gentryfikacja turystyczna - widoczna także w polskich (i środkowoeuropejskich) atrakcyjnych turystycznie obszarach miejskich - jest procesem znaczącym? Jakie są jej konsekwencje dla rozwoju miast 
Polski oraz Europy Środkowej i Wschodniej? Jak odmienne są jej trajektorie i na ile wiążą się one z socjalistycznym etapem w ich historii? Jak silne są jej związki z innymi procesami miejskiej zmiany? Kim są aktorzy? Jak często i w jaki sposób gentryfikacja turystyczna wiąże się z polityką miejską i publicznymi programami rewitalizacji? Jaki jest faktyczny bilans efektów? Jakie znaczenie w tym procesie mają big data? Jaka jest jego rola w konstytuowaniu hipertrofii turystycznej współczesnego miasta? Odpowiedzi na te i inne wciąż pojawiające się pytania wymagają dalszych pogłębionych studiów i refleksji naukowej. Zaskakujące bowiem „jak mało wiemy na temat związków między turystyką miejską i szeroko badaną gentryfikacją, prawdopodobnie jedną z najbardziej widocznych manifestacji turystyki w miejskich krajobrazach" (Herrera i in. 2007, s. 276).

\section{Literatura}

Anguelovski I., Connolly J.J., Masip L., Pearsall H., 2018, Assessing green gentrification in historically disenfranchised neighborhoods: a longitudinal and spatial analysis of Barcelona, Urban Geography, 39 (3), 458-491.

Arias-Sans A., Quaglieri Dominguez A., 2016, Unravelling Airbnb: Urban perspectives from Barcelona, [w:] A.P. Russo, G. Richards (red.), Reinventing the Local in Tourism: Producing, Consuming and Negotiating Place, Channel View Publications, Bristol, 209-228.

Ashworth G., Page S., 2011, Urban tourism research: Recent progress and current paradoxes, Tourism Management, 32 (1), 1-15.

Atkinson R., Bridge G. (red.), 2005, Gentrification in a global context. The new urban colonialism, Routledge, London.

Bardzińska-Bonenberg T., 2012, O gentryfikacji zabytkowych rejonów w Poznaniu, Czasopismo Techniczne, 109, 1, s. 43-52.

Bartkowski J., 2016, City as an entertainment machine (miasto jako maszyna rozrywki) - koncepcje rozwoju miejskiego i polityki miejskiej Terry'ego Nicholsa Clarka, Studia Miejskie, 21, 117-133.

Baudrillard J., 2005, Symulakry i symulacja, Królak S. (przeł.), Sic!, Warszawa.

Baudry S.L., 2017, Rome: a cultural capital with a poorworking-class heritage, [w:] M. Gravari-Barbas, S. Guinand (red.), Tourism \& gentrification in contemporary metropolises: International perspectives, Taylor \& Francis, 134-149.

Bock K., 2015, The changing nature of city tourism and its possible implications for the future of cities, European Journal of Futures Research, 3 (1), 3-20.

Bures R., Cain C., 2008, Dimensions of gentrification in a tourist city, referat na Meeting of the Population Association of America (http://paa2008.princeton.edu/papers/81623; dostęp: 05.11.2017).

Chapuis A., Gravari-Barbas M., Jacquot S., 2015, Tourism/Gentrification: Sex, gender and crossed resistances, referat na Association of American Geographer Annual Meeting Chicago, https:// www.academia.edu/12256317/Tourism_Gentrification_sex_gender_and_crossed_resistances (6.11.2017). 
Colomb C., Novy J. (red.), 2017, Protest and resistance in the tourist city, Routledge, London.

Cócola-Gant A., 2016, Holiday rentals: The new gentrification battlefront, Sociological Research Online, 21(3), 1-9.

Derek M., 2011, Od miasta præemystowego do miasta rozrywki? Turystyka, rozrywka i miasto polskie w latach 1989-2009, [w:] B. Krakowiak, J. Latosińska (red.), Turystyka polska w latach 1989_ 2009, Warsztaty z Geografii Turyzmu, t. 1, Wydawnictwo Uniwersytetu Łódzkiego, Łódź.

Dumbrovská V., 2017, Urban tourism development in Prague: from tourist mecca to tourist ghetto, [w:] Tourism in the City, Springer International Publishing, 275-283.

Dumbrovská V., Fialová D., 2014, Tourist intensity in capital cities in Central Europe: comparative analysis of tourism in Prague, Vienna and Budapest, Czech Journal of Tourism, 3 (1), 5-26.

Działek J., Murzyn-Kupisz M., 2015, Zachowania i preferencje przestræenne mtodych artystów w mieście na przykładzie Krakowa i Katowic, [w:] P. Trzepacz, J. Więcław-Michniewska, A. Brzosko-Sermak, A. Kołoś (red.), Miasto w badaniach geografów, t.1, Instytut Geografii i Gospodarki Przestrzennej, Uniwersytet Jagielloński, Kraków, 91-120.

Füller H., Michel B., 2014, Stop being a tourist! New dynamics of urban tourism in Berlin-Kreuzberg, Journal for Urban and Regional Research, 38 (4), 1304-1318.

Gaczek W. M., Kaczmarek M., Marcinowicz D., 2006, Poznański ośrodek akademicki: próba określenia wptywu studentów na rozwój miasta, Bogucki Wydawnictwo Naukowe, Poznań.

Gaffney Ch., 2015, Gentrifications in pre-Olympic Rio de Janeiro, Urban Geography, 37 (8), 1132-1153.

Glass R.L., 1964, London: aspects of change, Mac Gibbon \& Kee, Londyn.

Główczyński M., 2017, Gentryfikacja miast-przeglad literatury polskiej i zagranicznej, Rozwój Regionalny i Polityka Regionalna, 39, 61-78.

Gotham K.F., 2005, Tourism gentrification: The case of new Orleans' Vieux Carre (French Quarter), Urban Studies, 42 (7), 1099-1121.

Gould K., Lewis T., 2012, The Environmental injustice of green gentrification: The Case of Brooklyn's Prospect Park, [w:] J. DeSena, T. Shortell (red.), The World in Brooklyn: gentrification, immigration, and ethnic politics in a global city, Lexington Books, Lanham, 113-146.

Górczyńska M., 2015, Gentryfikacja w polskim kontekście: Krytycæny præeglad koncepcji wyjaśniajacych, Przegląd Geograficzny, 87(4), 589-612.

Gravari-Barbas M., Guinand S. (red.), 2017, Tourism \& gentrification in contemporary metropolises: International perspectives, Taylor \& Francis, Abingdon, UK.

Groyecka D., 2014, Gentryfikacja Berlina: od życia na podstuchu do kultury caffé latte, Wydawnictwo Naukowe Katedra, Gdańsk.

Grzeszczak J., 2010, Gentryfikacja osadnictwa: charakterystyka, rozwój koncepcji badawczej i przeglad wyjaśnień, PAN IGiPZ, Warszawa.

Gutierrez J., Garcia-Palomares J.C., Romanillos G., Salas-Olmedo M.H., 2016, Airbnb in tourist cities: Comparing spatial patterns of hotels and peer-to-peer accommodation, Tourism Management, 62, 278-291.

Guttentag D., 2015, Airbnb: disruptive innovation and the rise of an informal tourism accommodation sector, Current issues in Tourism, 18 (12), 1192-1217. 
Herrera L.M.G., Smith N., Vera M.Á.M., 2007, Gentrification, displacement, and tourism in Santa Cruz de Tenerife, Urban Geography, 28 (3), 276-298.

Hiernaux D., González C.I., 2014a, Turismo y gentrificación:pistas teóricas sobre una articulación, Revista de Geografía Norte Grande, 58, 55-70.

Hiernaux D., González C.I., 2014b, Gentrificación, simbólica y poder en los centros históricos: Querétaro, México, Scripta Nova. Revista Electrónica de Geografía y Ciencias Sociales, 18, 1-15.

Hoffman L., Fainstein S., Judd D. (red.), 2003, Cities and visitors. Regulating people, markets and city space, Oxford, UK: Blackwell.

Huning S., Novy J., 2006, Tourism as an engine of neighborhood regeneration? Some remarks towards a better understanding of urban tourism beyond the 'Beaten Path', CMS Working Paper Series, Center for Metropolitan Studies, 1-19.

Iwanicki G., Dłużewska A., Kay M. S., 2016, Assessing the level of popularity of European stag tourism destinations, Quaestiones Geographicae, 35 (3), 15-29.

Jadach-Sepioło A., 2009, Gentryfikacja w kontekście rewitalizacji, [w:] A. Zborowski (red.), Demograficzne i spoteczne wwarunkowania rewitalizacji miast w Polsce, Instytut Rozwoju Miast, Kraków, s. 125-135.

Jakóbczyk-Gryszkiewicz J. (red.), 2012, Procesy gentryfikacji w mieście. XXV Konwersatorium Wiedzy o Mieście, Wydawnictwo Uniwersytetu Łódzkiego, Łódź.

Jakóbczyk-Gryszkiewicz J., Marcińczak S., Wolaniuk A., 2014, Gentrification processes in the city, Łódź University Press, Łódź.

Janoschka M., Sequera J., Salinas L., 2014, Gentrification in Spain and Latin America - a Critical Dialogue, International Journal of Urban and Regional Research, 38 (4), 1234-1265.

Jansen-Verbeke M., 2011, Studia nad turystykq miejskq: stare opowieści nowe scenariusze,[w:] B. Włodarczyk (red.), Turystyka, Wydawnictwo Uniwersytetu Łódzkiego, Łódź, 87-104.

Judd D.R., 1999, Constructing the tourist bubble, [w:] D.R. Judd, S.S. Fainstein (red.), The tourist city, Wyd. Yale University Press, New Haven, Londyn, 35-53.

Judd D.R., 2003, Visitors and spatial ecology of the city, [w:] L.M. Hoffman, S.S. Fainstein, D.R. Judd (red.), Cities and visitors, Blackwell, Oxford-Malden, 23-39.

Kaczmarek S., 1999, Rewitalizacja a organiæacja præestræeni miejskiej, [w:] I. Jażdżewska (red.), Præestrzen miejska, jej organizacja i przemiany, XII Konwersatorium Wiedzy o Mieście, Wydawnictwo Uniwersytetu Łódzkiego, Łódź, 43-49.

Karwińska A., 2008, Gospodarka præestrzenna. Uwarunkowania spotecæno-kulturowe, Wydawnictwo Naukowe PWN, Warszawa.

Kotus J., Rzeszewski M., Bajerski A., 2015, Przyjezdni w strukturze miasta: miasto wobec præyjezdnych: studenci i turyści w miescie w kontekście koncepcji „city users”, Bogucki Wydawnictwo Naukowe, Poznań.

Kowalczyk A., Derek M., 2015, Præestrzeń czasu wolnego w polityce dużych miast, Ruch Prawniczy, Ekonomiczny i Socjologiczny, 77 (1), 311-325.

Kowalczyk-Anioł J., 2017, The Venice syndrome of heritage cities. Evidences of tourism development dysfunctions in Poland, [w:] Designing for co-creation in Euro-Asian tourism, Proceedings of the EATSA Conference, 21-25.08. 2017, Nara - Shirahama, 28-39. 
Kowalczyk-Anioł J., Afshar A., 2018, Gentryfikacja turystyczna jako narzedzie rozwoju miasta. Przyktad Mes:hed w Iranie, Turystyka Kulturowa, 2, 7-25.

Kowalczyk-Anioł J., Włodarczyk B., 2017, Præestræen turystycæna præestrzeniq konfliktu, Prace i Studia Geograficzne, 62 (2), 55-73.

Kowalczyk-Anioł J., Zmyślony P., 2017, Turystyka miejska jako \&ródto protestów spotecznych: przyktady Wenecji i Barcelony, Turystyka Kulturowa, 2, 7-36.

Lees L., 2003, Super-gentrification: the case of Brooklyn Heights, New York City, Urban Studies 40 (12), 2487-2509.

Lees L., Annunziata S., Rivas-Alonso C., 2018, Resisting planetary gentrification: the value of survivability in the fight to stay put, Annals of the American Association of Geographers, 108 (2), 346-355.

Lees L., Ley D., 2008, Introduction to special issue on gentrification and public policy, Urban Studies, 45 (12), 2379-2384.

Lees L., Slater T., Wyly E., 2008, Gentrification, Routledge, New York-London.

Lew A., 2017, Tourism planning and place making: place-making or placemaking?, Tourism Geographies, 19 (3), 448-466.

Ley D., 2003, Artists, aestheticisation and the field of gentrification, Urban Studies, 40 (12), 2527-2544.

Liang Z. X., Bao J. G., 2015, Tourism gentrification in Shen:hen, China: causes and socio-spatial consequences, Tourism Geographies, 17 (3), 461-481.

Liniany, J., 2015, O wwiqzkach turystyki \& præestræeniq miejskq -,,stare miasto” jako symulacja, Turystyka Kulturowa, 10, 58-71.

Lisowski A., 1999, Koncepcja gentryfikacji jako præejaw tendencji integracji w geografii miast, [w:] I. Jażdżewska (red.), Zróżnicowanie præestrzenne struktur spotecznych w dużych miastach. XII Konwersatorium Wiedzy o Mieście, Wydawnictwo Uniwersytetu Łódzkiego, Łódź, 23-32.

Łaszkiewicz E., Kronenberg J., Marcińczak S., 2018, Attached to or bound to a place? The impact of green space availability on residential duration: The environmental justice perspective, Ecosystem Services, 30, 309-317.

Maik W., 2013, Procesy gentryfikacji w mieście postindustrialnym - rola debaty gentryfikacyjnej we wspótczesnych studiach miejskich, podstawowe kwestie i spory badawcze, [w:] J. Jakóbczyk-Gryszkiewicz (red.), Procesy gentryfikacji w mieście. Cięś́ II, XXVI Konwersatorium Wiedzy o Mieście, Wydawnictwo Uniwersytetu Łódzkiego, Łódź, 11-19.

Maik W., 2016, Nowe ujęcia i koncepcje badawcze w studiach nad wspótczesnym miastem. [w:] T. Marszał (red.), Miasto-region-gospodarka w badaniach geografic:nych. W stulecie urodzin Profesora Ludwika Straszewicza, Wydawnictwo Uniwersytetu Łódzkiego, Łódź, 63-74.

Maitland R., Newman P. (red.), 2009, World tourism cities. Developing tourism off the beaten track, Routledge, Abingdon.

Marcuse P., 1985, Gentrification, abandonment, and displacement: Connections, causes, and policy responses in New York City, Journal of Urban and Contemporary Law, 28, 195-240.

Martinotti G., 1996, Four populations: Human settlements and social morphology in contemporary metropolis, European Review, 4 (1), 1-21. 
Mermet A. C., 2017, Airbnb and tourism gentrification. Critical insights from the exploratory analysis of the 'Airbnb syndrome' in Reykjavik, [w:] M. Gravari-Barbas, S. Guinand (red.), Tourism \& gentrification in contemporary metropolises: International perspectives, Taylor \& Francis, 52-74.

Minca, C., 2000, 'The Bali Syndrome': The explosion and implosion of'exotic'tourist spaces, Tourism Geographies, 2 (4), 389-403.

Minoia P., 2017, Venice reshaped? Tourism gentrification and sense of place, [w:] N. Bellini, C. Pasquinelli (red.), Tourism in the city. Towards an integrative agenda on urban tourism, Heidelberg: Springer, 261-274.

Murzyn-Kupisz M., 2012, Cultural quarters as a means of enhancing the creative capacity of Polish cities? Some evidence from Cracow, Quaestiones Geographicae, 31 (4), 63-76.

Murzyn-Kupisz M., Szmytkowska M., 2015, Studentification in the post-socialist context: The case of Cracow and the Tri-City (Gdansk, Gdynia and Sopot), Geografie, 120 (2), 188-209.

Murzyn-Kupisz M., Działek J., 2017, Theorising artists as actors of urban change, [w:] The impact of artists on contemporary urban development in Europe, Springer, Cham, 1-44.

Nofre J., Giordano E., Eldridge A., Martins J. C., Sequera J., 2017, Tourism, nightlife and planning: challenges and opportunities for community liveability in La Barceloneta, Tourism Geographies, 1-20.

Novy J., 2017, 'Destination'Berlin revisited. From (new) tourism towards a pentagon of mobility and place consumption, Tourism Geographies, 1-25.

Novy J, Colomb C., 2017, Urban tourism and its discontents: an introduction, [w:] C. Colomb, J. Novy (red.), Protest and resistance in the tourist city, Routledge, London, 1-30.

Opillard F., 2017, From San Francisco's 'Tech Boom 2.0' to Valparaiso's UNESCO World Heritage Site, [w:] C. Colomb, J. Novy (red.), Protest and resistance in the tourist city, Routledge, London, 129-151.

Parysek J., 2016, O najblïssej przysztości rewitalizacji w Polsce: pragmatycznie i prognostycznie, Problemy Rozwoju Miast, 4, 5-17.

Pawlusiński R., 2017, Ekonomia wspótdzielenia: istota wjawiska $i$ wyzwania dla sektora turystyki w miastach, [w:] M. Drewnik, M. Mika (red.), Citowiek i jego dziatania. Spojrzenie geografa. Prace dedykowane Profesorowi Wtodzimiersowi Kurkowi, Instytut Geografii i Gospodarki Przestrzennej, Uniwersytet Jagielloński, Kraków, 179-191.

Pinkster F., Boterman W., 2017, When the spell is broken: gentrification, urban tourism and privileged discontent in the Amsterdam canal district, Cultural Geographies, 24 (3), 457-472.

Rewers E., 2015, Co studentyfikacja ma wspólnego z gentryfikacja?, Rozwój Regionalny i Polityka Regionalna, 31, 57-66.

Richards G., 2014, The challenges of creative tourism. Retrieved from https://www.academia. edu/6112443/Challenges_of_creative_tourism (15.11.2017).

Russo A.P., Quaglieri Dominguez A., 2014, The spatial logic of the exchange: an approach to the new geographies of the everyday in contemporary tourism, Scripta Nova Revista Electrónica de Geografía y Ciencias Sociales, 18 (483), 1-34.

Russo A.P., Scarnato A., 2016, Barcelona in common: Reclaiming the right to the tourist city, http:// www.academia.edu/30959667/BARCELONA_IN_COMMON_RECLAIMING_THE_ RIGHT_TO_THE_TOURIST_CITY (26.10.2017). 
Sassen S., 1999, Globalization and its discontents: Essays on the new mobility of people and money, New Press, New York.

Sequera, J., Rodríguez, T., 2017, Turismo, abandono y desplazamiento: Mapeando el barrio de La Boca en Buenos Aires, Journal of Latin American Geography, 16 (1), 117-137.

Shaw J., Graham M., 2017, An informational right to the city? Code, content, control, and the urbanization of information, Antipode, 49 (4), 907-927.

Shin H.B., 2010, Urban conservation and revalorisation of dilapidated historic quarters: the case of Nanluoguxiang in Beijing, Cities, 27, 43-54.

Skoll G.R., Korstanje M., 2014, Urban heritage, gentrification, and tourism in Riverwest and El Abasto, Journal of Heritage Tourism, 9 (4), 349-359.

Smith N., 2002, New globalism, new urbanism: gentrification as global urban strategy, Antipode, 34 (3), 427-450.

Smith D., 2008, The politics of studentification and '(un)balanced' urban populations: lessons for gentrification and sustainable communities?, Urban Studies, 45 (12), 2541-2564.

Stors N., Kagermeier A., 2017, The sharing economy and its role in metropolitan tourism, [w:] M. Gavari-Barbas, S. Guinand (red.), Tourism \& gentrification in contemporary metropolises, Routledge, London, 221-248.

Szafrańska E., 2012, Gentryfikacja wielkich osiedli miesækaniowych - nowe sjawisko czy nadu:ycie terminologiczne?, [w:] J. Jakóbczyk-Gryszkiewicz (red.), Procesy gentryfikacji w mieście, cz. I. XXV Konwersatorium Wiedzy o Mieście, Wydawnictwo Uniwersytetu Łódzkiego, Łódź, 153-167.

Szahaj A., 2004, Zniewalajqca moc kultury. Artykuty i szkice \& filozofii kultury, poznania i polityki, Wydawnictwo Uniwersytetu Mikołaja Kopernika, Toruń.

Urry J., 2007, Spojrzenie turysty, Wydawnictwo Naukowe PWN, Warszawa.

Węcławowicz G., 2007, Geografia spoteczna miast. Uwarunkowania spoteczno-przestrzenne, wyd. II zm., Wydawnictwo Naukowe PWN, Warszawa.

Yrigoy I., 2016, The impact of Airbnb in the urban arena: towards a tourism-led gentrification. The case-study of Palma old quarter (Mallorca, Spain), Turismo y crisis, turismo colaborativo y ecoturismo., XV Coloquio de Geografía del Turismo, el Ocio y la Recreación de la AGE, 281-289.

Zborowski A., 2005, Przemiany struktury spoteczno-præestrzennej regionu miejskiego w okresie realnego socjalizmu i transformacji ustrojowej (na przyktadzie Krakowa), Instytut Geografii i Gospodarki Przestrzennej, Uniwersytet Jagielloński, Kraków.

Zukin S., 1989, Loft living: Culture and capital in urban change, Rutgers University Press.

Zukin S., 2008, Consuming authenticity, Cultural Studies, 22 (5), 724-728.

\author{
Joanna Kowalczyk-Aniot \\ Uniwersytet Łódzki \\ Wydziat Nauk Geograficznych \\ Instytut Geografii Miast i Turyzmu \\ ul. Kopcińskiego 31, 90-142 Łódź \\ joanna.kowalczyk@geo.uni.lodz.pl
}

